\title{
Education as Market Product: Identification Problems
}

\author{
Kateryna V. Astakhova1 \\ Victor V. Astakhov² \\ Sergey S. Shestopal ${ }^{1}$ \\ ${ }^{1}$ Vladivostok State University of Economics and Service \\ ${ }^{2}$ Kharkiv University of Humanities "People's Ukrainian Academy"
}

Doi:10.5901/mjss.2015.v6n6s3p211

\begin{abstract}
The analysis of the activity of the education market is carried out in the present paper. The types of market structures at the education market in the conditions of high schools competition are considered. The characteristics of the university as a legal economic and functioning subject are given. The supply and demand of the educational product characteristics are determined. The central issue of the universities positioning in the modern economic conditions is defined. The legal status, the education competitive strategy and competitive advantages of the university are given. Several strategies to improve competitiveness are suggested: the horizontal and vertical integration processes. Horizontal - the entrepreneurial activities of the university, the expansion of educational services, internationalization of education and integration into the international educational space and integration processes "university-science-business." Vertical - introduction of the concept of lifelong education, "schooluniversity-business." Both of them are considered to be rather competitive and their mutual penetration seems to be an efficient trend.
\end{abstract}

Keywords: educational institutions, education, market agents.

\section{Introduction}

Today, in the age of globalization and information, education is an institution of socialization, coordination and practical integration of generations, providing professionalized transformation of socially significant information into knowledge, which convey generalization and potential smoothing sharp edges of the national inconsistencies arising from traditional norms and rules that make up the national characteristics of the cultural heritage. Education institutionalizes information and knowledge accumulated previously, i.e. turns it into an instrument of sustainable removal of uncertainty, as well as an instrument of national or international influence on the intelligence of people. Education is an institutional filter: if the information transformed into knowledge, and knowledge into rules, patterns and norms, then information entered in the social organism, that is, it passed the process of knowledge institutionalization, which is possible due to the implementation of educational activities.

On the other hand, education is a personal, individual property, the main profit of which has economic properties, because later it is embodied to the income level of its owner. The institute of education is aimed at equipping the consumer of educational services with knowledge and competencies that will open access to obtaining the certain social position and material income. People treat knowledge as something that belongs to them, for the benefits of education that used in work and social activities. In this sense, the attitude of every person to education as to the general condition of their vital activity is a part of the common property (Mordovtsev, A.Y., Mordovceva, T.V. \& Mamychev, A.Y., 2015).

However, because of the complexity of the object under investigation and the needs for a multidisciplinary approach, this issue is still under the study and development. Among insufficiently studied are numerous theoretical questions that have to reveal the content of the concepts and problems: "economics of education", "institute of education", "entrepreneurial university", "competitive university," the problem of equilibrium in the education market, the economic functions of the institution of education, their importance in ensuring the stabilization of social economic development of the state in a market economy. 


\section{Overview of the State of the Problem}

The economic nature of education has been recognized by the classics of economics in the framework of the value labor theory. Many questions are described: the productive and efficiency education nature as a human capital investment in its future (Adam Smith); the analysis of the education costs as part of the of the labor power reproduction cost (D.Ricardo); the wages dependence on the education spending level (K.Marx); the education investments that considered to increase not only the human capital growth of its own productivity, but also for other workers (A. Marshall); the correlation of education investments in the economy and the GDP growth rate(M. Keynes); human capital as an external production factor, that is raising the economy productivity and efficiency (R. Solow).

In recent years, a number of studies of correlation between level of education and GDP growth has been conducted (Hanushek \& Vosmann, 2012). It identified the importance and value of education for the promotion of research and development, as well as for the dissemination of technologies (Vandebush). It was found that the higher percentage of educated people in the country's population, the higher the rate of economic growth (Maddison, 2006). The rate of human capital formation or investment in education was identified early on as a key influence on rates of economic growth (Barro, 1991) and growth theorists now place great emphasis on this variable as a determinant of the wealth of nations. Lucas (1988) developed an endogenous (within the economy) growth model that considers human capital as one factor of production and schooling as a means of human capital accumulation (Harmon, 2006).

Today special importance is given to the problems of the transformation of the education institution in the period of globalization, unification and standardization, as well as between technology and the information revolution, which generate the need for the new educational forms that can flexibly respond to changing demands for knowledge and professional skills. This problem is reflected in the works of V.Andruschenko, V.Bochkova, K Wazzin, T. Voronininoy, M. Galushkina, V.Gurova, A. Davydov, A. Yegorovna, O.Ereminoy, V. Zhuravsky, C Zahariya, I. Kalenyuk. A., S. Krihels, V.Kutsenko V. Logacheva, S. Mihats, E.Morgunova, S. Nikolaenko, E. Pakhomov, A. Petrov, N. Pruel, V.Tambovtseva, E. Hershberg.

\section{Methods and Materials}

Scientific methods of systematic and comprehensive approach are served as methodology of the study: historical and logical method is allows to reveal the nature of the historical educational forms and its relationship with the economic system; dialectical method, on the basis of which has been verified by contradictory nature of the functions and status of educational activities and its role in the development of economic systems; induction and deduction methods which made possible to generalize and systematize the modern trends of development of institutional reforms of educational activities; method of analysis and synthesis that are characterized by patterns of institutional development of educational activities to enable it to organically be involved in the process of globalization and socialization of economics; method of institutional approach, which has allowed to present an educational segment of the economic system as a set of rules, regulations, traditions and special organizations (educational institutions), which provide the process of education transmission of socially significant information.

\section{Results and Discussions}

Economic theory defines the Institute of Education as one of the most important socio-economic and law institutions, functioning in order to meet the demand of society for educational product and flexible in responding to all the social changes and processes. Institute of Education today ceases to act as a center of social and cultural values transmission, and becomes a producer of high-value products, as a set of educational goods and educational services. This product is formed as a result of treatment with the help of educational tools and is estimated on the labor market by a potential employer.

Educational product is a result of the production process in the educational activity, in which knowledge is a kind of commodities, represented as a set of specific professional data. The result of the operation of the education institution embodied in the form of a commodity is a diploma of the particular speciality, which serves as a commodity purchased by the consumer.

Gaining knowledge by the society is realized through educational activities, as a result of which an institution provides educational product to the consumer. Considering the results of educational activity, that is, the knowledge obtained by the consumer and embodied in the form of commodity as a state diploma of certain speciality, one should pay attention to the specific characteristics of education as a commodity, i.e. a public good. Education as a public good is 
a result of a long historical social evolution of a society. Consolidating the results of science, education develops cognitive and practical properties of a social person, enabling them to meet continuously rising social needs. It helps the action of complex mechanisms in individual and social human activity, reproduces integration and differentiation of diverse social ties. According to the current scientific understanding educational product is an economic product, which is interpreted as the result of economic activity and is presented in the material form as fulfilled works and provided services that could be provided to the consumer during his life time.

One of the main tasks of legislation in the sphere of education is to ensure and protect citizens' constitutional right to education, and to create legal guarantees for the free functioning and development of both the educational system as a whole and all its components. Inadequate provision of the above guarantees by states is a hindrance in the realization of the planned reforms. Academic literature contains very different, sometimes even mutually exclusive interpretations of the concept of "lifelong education", from the emergence of a new, global educational system to the principle of continuity that becomes decisive for the functioning of any educational system during the epoch of globalization (Lyubashits, V.Y., Mordovtsev, A.Y. \& Mamychev A.Y, 2015). The opportunity to get a free professional education only once in one's lifetime, and the duty to "work out one's diploma" for several years, were not conducive to people's self-improvement and permanent creative growth. Furthermore, the basic knowledge one received was virtually sufficient for a lifetime. The opportunities for lifelong education that were created by those circumstances allegedly gave a powerful impetus to the development of lifelong education. (Innovative search continues..., 2010)

From the economic point of view knowledge is a commodity in the relations of commodity-monetary exchange and are traded in the market of educational services, education can also be seen as an institution of social and economic exchange. Education offers the market a product that, as well as any product of exchange, has a use value and exchange value, i.e. the ability to meet the needs of the consumer, which is reflected in consumer utility from consumption of educational services and the ability to exchange into the money that is paid by the consumer of an educational product.

An educational product may be represented in the form of commodities as knowledge, which is set of information of a specific vocational orientation, collected into educational programs within a particular speciality. The result of this commodity form embodiment is a diploma which, being bought and sold in the market of educational services, serves as goods in commodity-money exchange, both at the education market and the labor market.

The model of market relations in the higher education system is presented regarding the relationship between higher education institutions engaged in training and retraining of young professionals, between enterprises, which are consumers of young professionals, and young professionals themselves as specific goods, produced as a result of educational services. However, due to the same reason, parents, school, environment, and surrounding people, as well as the graduate himself could be called the manufacturer of this particular product. This is confirmed by the fact that in the formation of professionally significant knowledge and skills that are used by employers in the labor market, not only the university is involved, but also the family, environment. An important aspect here is the self-education in the period of study at the university, parallel training in various courses, getting extra experts. In addition, professional qualities can not be viewed in isolation from other personality characteristics that are significant during both employment, and occupation.

Another important dimension of education identification is considered from the point of view of the public, private or mixed benefit. Consideration of education from the perspective of a public good allows one to emphasize its fundamental property - non-competition, the essence of which is that every person originally acts as a co-owner of the knowledge belonging to the whole society. Consumption of education benefits by an individual should not be excluded from consumption of the results of their operation for other people, which characterizes the non-competition of education. Consumption of knowledge by certain people does not lead to a reduction in consumption of the same knowledge by others, since knowledge are inseparable. (Pruel, 2001)

When considering education as a public good and analyzing its external effect, the presence of high levels of uncertainty should be noted, which creates insurmountable difficulties of quantitative changes in the public benefit and creates the possibility of opportunistic behavior of the subjects of educational process. In addition, there are circumstances indicating irrational economic behavior of economic agents and the occurrence of information asymmetry, i.e. the uneven distribution of information between the state and citizens (Shestopal, S., 2014).

The main task of the education market is to balance the supply and demand of these services and meet their needs. Demand for educational product is determined by many social and psychological factors, starting with adherence to family traditions. From the point of view of economic motives, the most important is the salary that the consumer of educational services is able to receive after graduating from higher educational institution, and the prospect of return on investment in education. One can make the following assumptions about the demand for education:

- consumer demand, based on current consumption is less than the demand of those who are oriented toward 
future income (ceteris paribus);

- demand for contract training will decrease with an increase in the cost of education (ceteris paribus);

- demand will increase with an increase in the differences in earnings of persons with higher and secondary education in favor of the former;

- the demand for educational services to a particular profile is derived from the demand for specialists in this profile and the level of their income;

- with increase in the age of educational services' consumers, the alternative expenses rise as well, which makes the demand for educational services more flexible.

In the context of economic transformation the "non-functional demand" remains high enough and touches upon universities and specialties displaying a prestigious position in society, the so-called "Veblen Effect", which in opposition to the law of demand unreasonably puts up the prices for prestigious specialties. This applies to the world's most prestigious universities of Harvard and Stanford, as well as Russian (Moscow State University, MGIMO).

With regard to the analysis of the supply of education services, it should be remembered that the Institute of Education "forges personnel" and should therefore be focused on the needs of society in general and employers in particular. However, some difficulties and peculiarities should be pointed out. An educational institution operates simultaneously in two markets: the education market and the labor market. The university provides educational services of a certain type to the society and at the same time presents the results of its activities to the labor market, consumers of which are businesses and organizations in different fields of economy. This dual nature of the university activity is making considerable confusion in the definition of its products, target markets and consumer groups.

The supply of educational services within a single educational space is carried out by state and private universities, which occupy one third of the market and increase competition. Given the market structure the market of educational services is a market of monopolistic competition. This is implied by: firstly, educational product differentiation both as to its consumer characteristics and in terms of the quality. It is referred to education in different fields, faculties, universities and levels of teaching. Secondly, the high sensitivity to economic conditions, a significant factor of seasonality, a significant influence of advertising, fashion, awareness, education institute dependence of political and economic institutions. Thirdly, distinct segmentation of demand for services based on income, prices, users' subjective evaluation of the supplier's ability to provide certain services, the importance of a service, lifestyle. Fourthly, the general capacity of the market and the absolute benefits of existing enterprises in the industry on the costs of providing services and benefits to consumers, the positive effects of scale. (Astakhova, 2013)

It should be noted that the educational space within the market is non-uniform both in terms of students, educational institutions, and from the point of view of the proposed product. In one state, you can find a lot of educational institutions that due to a number of factors have different quantitative characteristics of educational space. These factors include the profile of the university, teaching personnel and different entry requirements. One of the main factors that determine the boundaries of the market is the price factor. However, today non-price factors are becoming more and more important in the competitive relationship in the market of educational services (Marginson, S., M. van der Wende, 2007).

This means that educational institutions are trying to attract the consumer using non-price methods, focusing on the range of additional related services, so-called complement services. The latter include: the organization of extracurricular activities, broadening the range of educational services through the provision of training on an additional speciality, organization of scientific activity of students, as well as scientific conferences and seminars.

The implementation of lifelong multilevel education must lead to the creation of educational institutions with a multilevel organization of students training. Training in such institutions must be implemented according to integrated curricula and educational programs of various educational levels: primary, secondary, higher and supplementary ones. The upbringing component of the integrated training and upbringing process being implemented in the above structures must be an important component of their activity. Such activities may result in a network of educational institutions providing opportunities for a changeover to multi-level, multi-tier, successive and variable educational problems (Mukimbekov, M. 2011). Therefore, in spite of the fact that the overwhelming majority of educational institutions implement the idea of lifelong education in practice by organizing joint activities or creating associations of legal entities interconnected by an agreement or shared goals of the above concept, in our opinion, the concept of lifelong education can be implemented to the best extent in educational institutions (complexes) comprising all the basic educational activity structures, from preschool to postgraduate education, moreover, within the framework of a single legal entity (Raley, Y. \& Preyer, G., 2010).

One of the most powerful factors of non-price competition between universities is teaching personnel. Its qualitative 
characteristics can be divided into formal and informal. The former should include the number of academic degrees and titles per one school, to informal - the credibility of teaching staff, the nature and level of interpersonal relationships, the efficiency of their interaction, the ability to empathize (Vegelers, R., 2010). A significant role among the non-price factors is played by an opportunity to provide further employment of students, which opens the way for students to reduce the transaction costs of future job search with the necessary level of pay and prestige. The characteristic features of the educational market, like any other, are the uncertainty and risks, which include: "supply and demand shocks": changes in economic and political stability, a sharp change in prices for resources, in tax policy, as well as natural disasters (Rivkin, S., Hanushek, R. \& Kain, J., 2005).

Demand for the products of companies operating in a monopolistic competition is not perfectly elastic, but its elasticity is high. For example, the adherents of Western European education are willing to pay for it more than for domestic education - , but if the price difference is too large, then the buyer will always find in the market analogues of less well-known companies at a lower price. Therefore, the institutions that produce intellectual human capital should have a balanced approach to the positioning of their own advantages.

Unfortunately, the distinction between commercial and non-commercial organizations is the Achillean heel of the present-day civil legislation. The core of the problem is not only the choice of appropriate criteria for delimiting those types of organizations, but also consistent application of chosen criteria to various types of legal entities. In our opinion, since a private higher educational institution is defined in theory as a specific non-commercial higher educational institution established in accordance with the existing state legislation with the goal of carrying out business activities in the sphere of educational services rendering the basis of self-financing and self-control (Astakhov, 2014), we consider it expedient to codify non-commercial status for private higher educational institutions.

\section{Conclusions}

Activity of universities is carried out today in an increasingly competitive environment. This defines the policy of higher school institution, which tends to attract students and raise their ranking, to become competitive in the provision of qualitative educational services. Global trends in the development of education, require a deep and comprehensive renovation of the structure and content of higher education, consistent and prompt implementation of innovative technologies of training and education, modernization of the state educational policy, reviewing not only the legal basis for the functioning of higher education institutions but also revision of the mission of the higher school, its strategic objectives.

There are several strategies to improve competitiveness: the horizontal and vertical integration processes. Horizontal - the entrepreneurial activities of the university, the expansion of educational services, internationalization of education and integration into the international educational space and integration processes "university-sciencebusiness." Vertical - introduction of the concept of lifelong education, "school-university-business." Both of them seem to be promising within the frames of modern socio economic challenges.

\section{References}

Astakhov, V. (2014) Continuous education through the lens of time: monography. Pushkin Leningrad State University. Pushkin LSUKharkiv: pp. 208.

Astakhova, E. (2013) Education as a socio-economic market the product in the new historical conditions // Educational potential of the Kharkiv region: monograph / Nar. Ukr. Acad. Kharkiv. pp. 282-289.

Harmon, C. (2006) Economic and social impact of higher education. Irish universities association ,Geary institute.

Innovative search continues ... (from the global experience of formation of continuing education), 2010. Monograph. . Under the general ed. Doctor. East. Sciences, prof. V Astakhova Kharkov publishing house LSA. pp. 237.

Lyubashits, V.Y., Mordovtsev, A.Y. \& Mamychev A.Y. (2015) State and Algorithms of Globalization // Mediterranean Journal of Social Sciences. Vol 6, No 3 S6. pp. 269-277.

Marginson, S., M. van der Wende (2007) Globalisation and higher education. OECD. IS. Marginson, M. van der Wende. Education Working Papers, No. 8.

Mordovtsev, A.Y., Mordovceva, T.V. \& Mamychev, A.Y. (2015) The Convergence of Law: The Diversity of Discourses // Mediterranean Journal of Social Sciences. Vol. 6, № 3. pp. 257-26.

Mukimbekov, M. (2011) Economic nature of the education market, and some areas of the modernization of higher education. Economics of Education № 5. pp. 4-15.

Pruel, N. (2001) Education as a public good: the reproduction, distribution and consumption / NA Pruel; St. Peterbugr. state. Univ. SPb. pp. 187.

Raley, Y. \& Preyer, G. (2010) Philosophy of Education in the Era of Globalization, Taylor\& Francis, NY, Routledge. pp. 246. 
Rivkin, S., Hanushek, R. \& Kain, J. (2005) Teachers, Schools, and Academic Achievement. Econometrica 73.2 March: 417-458.

Shestopal, S. (2014) Political and Legal personalism and pluralism - J. Maritain's concept and treatment // Theory and practice of jurisprudence, 1(5), pp. 32.

Vegelers, R. (2010) Contribution of universities to economic development. Economics of Education. № 2. pp.74-80. 